\title{
Vegetation Composition in Hugumbirda-Gratkhassu National Forest Priority Area, South Tigray
}

\author{
Leul Kidane Woldemichael ${ }^{1 *}$, Tamrat Bekele ${ }^{2}$ and Sileshi Nemomissa ${ }^{2}$ \\ ${ }^{1}$ Abbi Adi College of Teacher Education, P.O.Box 11, Abbi Adi, Ethiopia (*leulkw@gmail.com) \\ ${ }^{2}$ Department of Biology, Addis Ababa University, P.O. Box 3434, Addis Ababa, Ethiopia.
}

\begin{abstract}
The floristic composition and structure of the vegetation of Hugumbirda-Grat-Khassu forest, South Tigray, Northern Ethiopia is described and related to environmental factors. To analyze the vegetation and environmental data seventy-four relevè ( $20 \mathrm{~m}$ x $20 \mathrm{~m}$ ) were used. For each species the cover/abundance value was estimated. Height and diameter at breast height (DBH) of all woody individuals taller than $2 \mathrm{~m}$ and thicker than $2 \mathrm{~cm}$ were measured. Importance Value Index was calculated for 24 tree/shrub species and the result helped to identify the five dominant tree/shrub species and to show the overall forest situation. The species and relevès were classified with the two-way indicator species analysis program TWINSPAN.

We recorded 102 species belonging to 83 genera and 50 families. Five community types are described: Allophylus macrobotrys-Ficus sur, Nuxia congesta-Podocarpus falcatus, Acacia abyssinica-Olea europaea, Myrica salicifolia-Erica arborea-Maesa lanceolata and Acacia etbaica-Dichrostachys cinerea-Acacia tortilis type. Of these, community type 2 has high species richness while community type 3 is poor in species richness. The general arrangement of all species was found to show high density at lower height and DBH classes. Based on the cumulative results of Importance Value Index, Juniperus procera, Olea europaea subsp. cuspidata, Nuxia congesta, Cassipourea mallosana and Olinia rochetiana were identified to be the most dominant tree species of the forest and they contributed $71.43 \%$ of the basal area. Analysis of community-environment relationships didn't show significant differences except for altitude and slope.
\end{abstract}

Key words: Community, DBH, Floristic composition, Forest structure, Releve, Vegetation classification.

\section{INTRODUCTION}

It is to be noted that Ethiopia is one of the centres of plant genetic diversity, and that its indigenous forests have been repositories of biodiversity including microorganisms, fungi, soil fauna and flora, medicinal plants, wild animals, birds, insects, as well as human beings (Tewolde Berhane Gebre Egziabher, 1990; Legesse Negash, 2002). According to Zerihun Woldu et al. (2002) and Zewge Teklehaimanot and Healey (2001), Ethiopia is endowed with rich fauna and flora because of its diverse ecological features, which make the country an important centre of diversity and endemism. World Conservation Monitoring Centre (WCMC) (1992) has pointed 
out that the flora of Ethiopia is very heterogeneous and has a rich endemic element. It is estimated to contain around 6500 to 7000 species of higher plants, of which about 12 percent are endemic (WCMC, 1992). Nevertheless, Zewge Teklehaimanot and Healey (2001) have noted that continued exploitation of natural forests without giving due consideration to their propagation, domestication and cultivation has resulted in a vicious cycle where increased forest destruction has led to increased scarcity and/or rarity of resources which in turn have resulted in increased demand and subsequent further destruction.

Tigray is one of the most environmentally degraded regions in Ethiopia, with very scanty vegetation. At present the original vegetation is found around churches where it is forbidden to cut trees and in other isolated and protected areas (Feoli, 1996). Mitiku Haile and Kindeya Gebremedhin (2000) stated that, misuse of natural resources has resulted in very serious land degradation in most places. The present arable land can no longer support the ever-increasing human population. Generally, it can be said that environmental degradation, drought and socioeconomic instability are common in contemporary Tigray.

To conserve the remaining natural forests of Ethiopia and the environment for the genetic resources and raw material for the industries, 58 National Forest Priority Areas (NFPA's) covering an area of 3.6 million hectares have been selected (SFCDD, 1990). However, various studies indicate that protection of these NFPA's has not been effective. The NFPA's failed to fully recognize the historical and customary rights and interests of local communities in forest products and forestlands. Local communities have frequently disregarded the boundaries established by the forestry sector on the notion that boundaries have violated their traditional access to and dependence on the forest resources.

According to Zerihun Woldu et al. (2002) improving the management of the natural resources while providing ecological services and immediate economic needs is the major research and development challenges for the degraded areas of northern Ethiopia in particular and drylands of east Africa in general. Thus, accommodating new conservation approaches such as participatory forest management can contribute significantly to mitigate the problem of forest destruction. The Hugumbirda-Grat-Khassu forest is one of the National Forest Priority Areas (NFPA's), which was identified with the aim to introduce improved management system. However, as the socioeconomic study of the area by Zenebe GebreEgziabher et al. (1998) have noted, with high population pressure and the increasing demand for agricultural land, the forest resource is on the 
verge of complete depletion. Encroachment of forestland and illegal cutting of trees are rampant and consequently the most valuable indigenous tree species as well as wild animals are becoming severely affected in the area. Therefore, in view of the need to develop more effective approaches to conservation and sustainable utilization of the forest resources, an investigation of the floristic composition and the relation to environmental factors was conducted.

\subsection{Description of the Study Area}

\subsubsection{Location}

Hugumbirda-Grat-Khassu National Forest Priority Area is located in the southern zone of Tigray at about $600 \mathrm{~km}$ north of Addis Ababa or some $160 \mathrm{~km}$ south of Mekele, the capital of Tigray Regional State. It is located between $12^{\circ} 22^{\prime}$ and $12^{\circ} 42^{\prime} \mathrm{N}$ latitude, $39^{\circ} 28^{\prime}$ and $39^{0} 40^{\prime} \mathrm{E}$ longitude (Fig. 1) at an altitudinal distributions from $1560 \mathrm{~m}$ to $2688 \mathrm{~m}$.

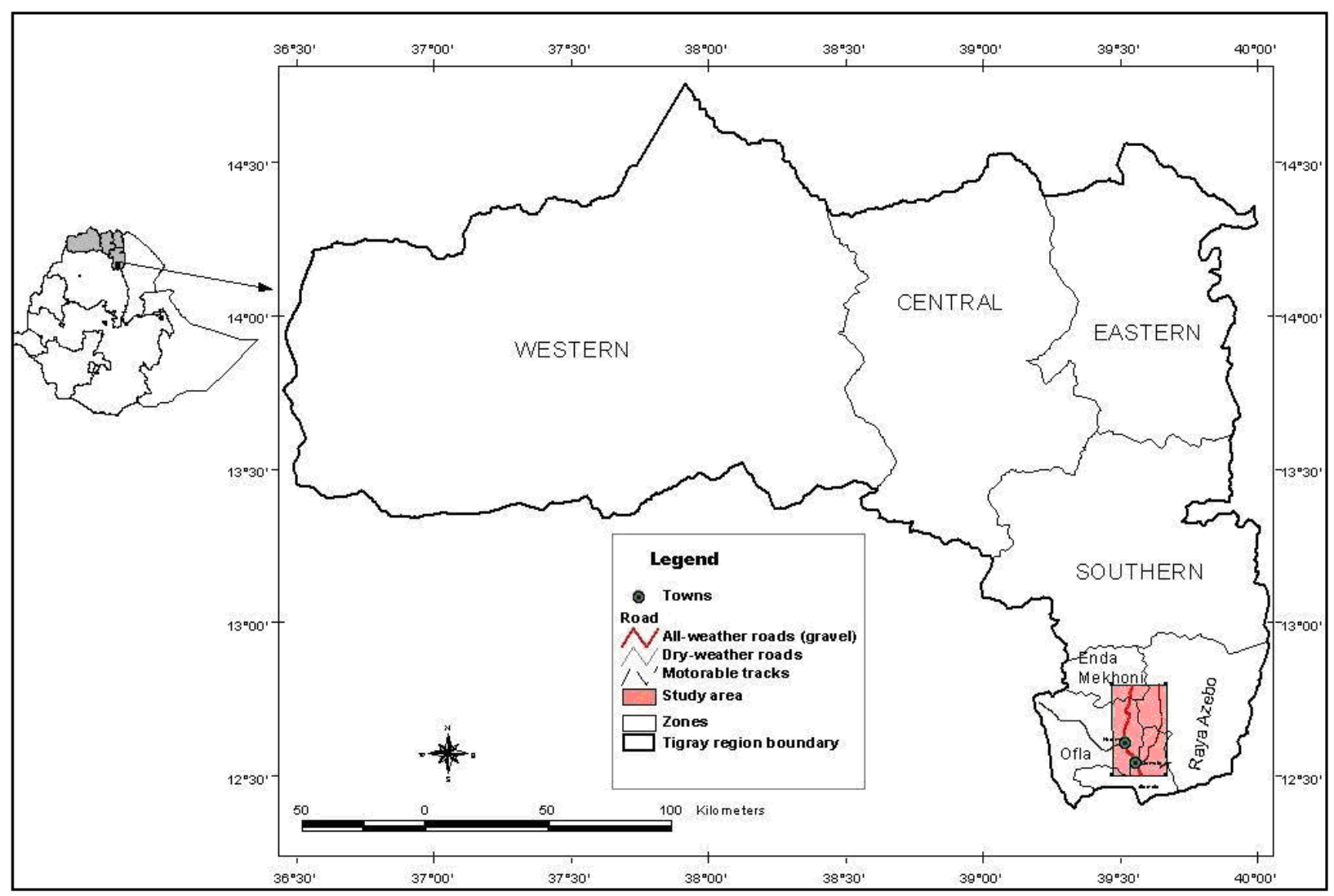

Figure 1. Map of the study area. 


\subsubsection{Climate}

Metrological data of monthly maximum and minimum temperature and monthly rainfall were taken from two stations (Alamata and Korem) for the period 1978 to 2001.One of the nearest metrological station is located in Alamata town at a distance of $5 \mathrm{~km}$ from Grat-Khassu. Here the mean annual minimum temperature is $14^{\circ} \mathrm{C}$ and the mean annual maximum temperature is $29.8^{\circ} \mathrm{C}$. The hottest month is June with a mean maximum temperature of $34.3^{\circ} \mathrm{C}$, and the coldest is October with a mean minimum temperature of $10.7^{\circ} \mathrm{C}$. The mean annual precipitation is 750.9 $\mathrm{mm}$.

The other nearest metrological station is in Korem town. Here the mean annual minimum temperature is $8.8^{\circ} \mathrm{C}$ and the mean annual maximum is $22.1^{\circ} \mathrm{C}$. The hottest month is June with a mean maximum temperature of $24.3^{\circ} \mathrm{C}$, and the coldest is December with a mean temperature of $6.1^{\circ} \mathrm{C}$. The mean annual precipitation is $998.9 \mathrm{~mm}$.

\subsubsection{Vegetation}

Formerly, the area was covered with dense forest composed of different indigenous species. According to Zenebe Gebre-Egziabher et al. (1998) and information obtained from local informants, the natural forest was exploited by Italian concessionary named Montu Doro who installed sawmills at Hugumbirda in 1950 with the permission of the then governor of Welo province.

The forest was officially put under the auspices of State Forestry Agency in 1965 (SFCDD, 1997). Then in 1981 the area was identified as one of the National Forest Priority Areas (NFPAs). Boundary demarcation, which is the basis for the current management of the forest, was undertaken in 1993. Based on this demarcation, the project covers a total area of 21, 654.24ha. Out of this about 532.75 ha is plantation forest whereas the rest contains disturbed natural high forest, bushes, shrubs, agricultural plots and settlement area.

\section{METHODOLOGY}

\subsection{Botanical composition survey}

Vegetation data was collected from 74 sample plots (relevè), size $20 \mathrm{mx} 20 \mathrm{~m}\left(400 \mathrm{~m}^{2}\right)$ following Kumlachew Yeshitla and Tamrat Bekele (2002) and Tesfaye Awas et al. (2001). During 
sampling, visually checked homogeneous, representative stands (Werger, 1974; Andreucci et al., 2000) were selected and delimited for sampling.

Plant species found within each relevè were recorded by their vernacular name and their cover/abundance (ground cover) percentage was estimated following the procedure of BraunBlanquet (Braun-Blanquet, 1965; Muller-Dombois and Ellenberg, 1974). The percent cover values, which are visually estimated in the field, were later converted into 1-9 modified BraunBlanquet scale (van der Maarel, 1979):

1. Rare-generally only one individual

2. Sporadic (few) -less than $5 \%$ cover of the total area

3. Abundant with less than $5 \%$ cover of the total area

4. Very abundant and less than 5\% cover of the total area

5. $5-12 \%$ cover of the total area

6. $12.5-25 \%$ cover of the total area

7. $25-50 \%$ cover of the total area

8. $50-75 \%$ cover of the total area

9. $75-100 \%$ cover of the total area

$\mathrm{DBH}$ (diameter at breast height) was measured at $1.3 \mathrm{~m}$ using callipers for shrubs and trees that had a DBH equal or greater to 2cm (Martin, 1995; Tuxill and Nabhan, 2001). Height of trees and shrubs greater or equal to $2 \mathrm{~m}$ was measured using hypsometer for taller trees and shrubs and measured pole marked at 0.5m intervals and 4m long (Tuxill and Nabhan, 2001;Bongers et al., 1988). The pole is held vertically at the base of the tree/shrub, enabling the observer standing far enough away from it to see the base and the top of the stem. The number of pole length was then counted to estimate the height of the plant. Those plant species having height and DBH less than two are counted by species.

\subsection{Environmental data}

The environmental variables measured for every stand (relevè) selected include altitude, slope, aspect (exposure), soil depth and estimate of grazing intensity and human impact.

Altitude was measured using an Everest Altimeter, slope was measured using clinometers, and Aspect was determined using Suunnto compass. As a possible indicator of total solar energy, 
aspect was codified according to Zerihun Woldu et al. (1989). Thus $\mathrm{N}=0$; $E=2 ; \mathrm{S}=4$; $\mathrm{W}=2.5$; $\mathrm{NE}=1 ; \mathrm{SE}=3 ; \mathrm{SW}=3.3$ and $\mathrm{NW}=1.3$

From the corners and centre of each stand, soil depth was measured using a measured long metal marked at $10 \mathrm{~cm}$ interval and $1.25 \mathrm{~m}$ long. Average depth of these measurements was then taken for the stand soil depth. Then nature of the measured depth was determined following Parent (2000). The details are described below.

$-<20 \mathrm{~cm}=$ very shallow

$-21-50 \mathrm{~cm}=$ shallow

$-51-100 \mathrm{~cm}=$ moderate deep

$->100 \mathrm{~cm}=$ deep

Grazing intensity was estimated following Kebrom Tekle et al. (1997) and Zerihun Woldu and Backeus (1991): 0= nil; 1= slight; 2= moderate and 3= heavy.

The state of human interference at each relevè was estimated following Gebremedhen Hadera (2000) and Kumlachew Yeshitla and Tamrat Bekele (2002) and with modifications. A 0-3 subjective scale was taken into consideration to record the presence or absence of stumps, logs and signs of fuelwood collection. Therefore, the magnitude of the impact was quantified as follows

$0=$ nil; 1 = low; 2= moderate; and 3=heavy

\subsection{Data analysis}

\subsubsection{Vegetation data}

Two-way indicator species analysis, which is a recommended technique for its robustness and effectiveness (Gauch and Whittaker, 1981), was used to classify the vegetation data. TWINSPAN is a divisive polythetic method of vegetation classification; it classifies both relevès and species. The computer program used was the TWINSPAN program (Hill, 1979). The groups obtained were characterized as local plant community types, and described as "type”, which were provisionally characterized by dominating and/or characteristic species, mainly trees and shrubs. A dominating species in this case is a species having a synoptic cover-abundance value (mean frequency x mean cover-abundance) (van der Maarel et al., 1978) of at least five, and a characteristic species having a high frequency in the type and a lower frequency in most other 
types. The community types identified were further characterized by means of environmental factors, which appeared to be correlated to the floristic composition of the type.

\subsubsection{Structural data}

The structure of the plants was described in terms of tree density, diameter and height. Tree density was computed by converting the count from the sample plot to a hectare basis. The diameter at breast height $(\mathrm{DBH})$ was classified into $14 \mathrm{DBH}$ classes and the percentage distribution of trees and shrubs in each class were computed. Height was classified into 9 height classes and the percentage distribution of the plants in each class was calculated.

The following parameters and index were calculated to determine the vegetation structure and the dominant species of the forest: for those individual species having $\mathrm{DBH}$ greater than $10 \mathrm{~cm}$ and relative frequency greater than $0.60 \%$, relative density, relative frequency, relative dominance and importance value index (IVI) (Muller-Dombois and Ellenberg, 1974; Misra, 1974) were calculated using the following formulae:

Relative density $=$ Number of individuals of a species/ Total number of individuals of all species X 100

Relative frequency $=$ Frequency of a species/ Sum frequency of all species x 100

Relative dominance $=$ Basal area of a single species/Total basal area of all species $\mathrm{x} 100$

Importance Value Index (IVI) = Relative density + Relative frequency + Relative dominance.

\subsubsection{Environmental data}

To get a mean value for the various environmental parameters of each distinct plant community type, the values for all the relevè that make up the particular community type were added and averaged. One-way analysis of variance (ANOVA) was performed to detect variation among the community types with respect to any one environmental parameter. Tukey's tests were performed to detect significant differences among the different means of the environmental parameters of each community types. The correlation of the various environmental parameters among each other was evaluated by calculating Pearson's product moment correlation coefficient. 
Meteorological data obtained from two stations of the study area were analyzed for mean monthly maximum and minimum temperature and mean monthly rainfall registered for 20 years. Clima diagram was produced from these results.

\subsubsection{Voucher Plant Specimen Collection and Identification}

Every time a new species was encountered in the relevè, a specimen was collected in duplicate, numbered, dried and placed in a reference collection following standard Herbarium procedures (Bridson and Forman, 1992). The specimens were then identified by comparing them with already identified specimens in the National Herbarium of Ethiopia (ETH) and by referring to Hedberg and Edwards (1989), Edwards et al. (1995), Edwards et al. (1997), Edwards et al. (2000), and Hedberg et al. (2003).

\section{RESULTS}

\subsection{Floristics}

A total of 102 species of plants representing 83 genera and 50 families were recorded from the study area (Appendix 1). Of these 24 (23.52\%) were trees, 18 (17.64 \%) tree/shrub, 47 (46.06 \%) shrubs, 2 (1.96 \%) shruby herb, 9 (8.82 \%) woody climbers (lianas) and 2 (1.96 \%) herbs. The comparative distribution of species within the families is given in Table 1.

\subsection{Vegetation Classification}

Five community types were obtained from the classification out put. Their description based on the dominant and characteristic species having synoptic cover-abundance values greater than one in at least one community type and their altitudinal distribution is as follows.

\subsubsection{Allophylus macrobotrys -Ficus sur type}

This community is found at altitude from 2215-2246. Allophylus macrobotrys is a dominant species and Ficus sur is characteristic species of the type. Associated species in the type include Ekebergia capensis, Teclea simplicifolia, Cassipourea malosana and Nuxia congesta. Regenerating species of Grewia mollis, Maytenus undata, Pavetta oliveriana, Vernonia rueppelli and Buddleja polystachya are abundant under the canopy layer. Woody climbers such as 
Clematis hirsuta, Cynanchum abyssinicum, Jasminum grandiflorum and Rhoicissus tridentate are common in the type.

Table 1. Family-wise percentage distribution of species.

\begin{tabular}{|llllllll|}
\hline No & Family & $\begin{array}{l}\text { Number } \\
\text { of species }\end{array}$ & $\boldsymbol{\%}$ & No & Family & $\begin{array}{l}\text { Number } \\
\text { of species }\end{array}$ & \% \\
\hline 1 & Acanthaceae & 1 & 0.98 & 26 & Moraceae & 2 & 1.96 \\
\hline 2 & Anacardiaceae & 3 & 2.94 & 27 & Myricaceae & 1 & 0.98 \\
\hline 3 & Apiaceae & 2 & 1.96 & 28 & Myrsinaceae & 2 & 1.96 \\
\hline 4 & Apocynaceae & 2 & 1.96 & 29 & Oleaceae & 2 & 1.96 \\
\hline 5 & Asclepiadaceae & 3 & 2.94 & 30 & Oliniaceae & 1 & 0.98 \\
\hline 6 & Asparagaceae & 1 & 0.98 & 31 & Phytolaccaceae & 1 & 0.98 \\
\hline 7 & Asteraceae & 7 & 6.86 & 32 & Pinaceae & 1 & 0.98 \\
\hline 8 & Balanitaceae & 1 & 0.98 & 33 & Pittosporaceae & 1 & 0.98 \\
\hline 9 & Berberidaceae & 1 & 0.98 & 34 & Podocarpaceae & 1 & 0.98 \\
\hline 10 & Boraginaceae & 3 & 2.94 & 35 & Polygonaceae & 1 & 0.98 \\
\hline 11 & Cactaceae & 1 & 0.98 & 36 & Ranunculaceae & 2 & 1.96 \\
\hline 12 & Capparidiaceae & 1 & 0.98 & 37 & Rhamnaceaae & 4 & 3.92 \\
\hline 13 & Celastraceae & 2 & 1.96 & 38 & Rhizophoraceae & 1 & 0.98 \\
\hline 14 & Cupressaceae & 2 & 1.96 & 39 & Rosaceae & 3 & 2.94 \\
\hline 15 & Ebenaceae & 1 & 0.98 & 40 & Rubiaceae & 3 & 2.94 \\
\hline 16 & Ericaceae & 1 & 0.98 & 41 & Rutaceae & 2 & 1.96 \\
\hline 17 & Euphorbiaceae & 2 & 1.96 & 42 & Santalaceae & 1 & 0.98 \\
\hline 18 & Fabaceae & 12 & 11.76 & 43 & Sapindaceae & 2 & 1.96 \\
\hline 19 & Flacourtiaceae & 2 & 1.96 & 44 & Solanaceae & 3 & 2.94 \\
\hline 20 & Hypericaceae & 1 & 0.98 & 45 & Sterculiaceae & 1 & 0.98 \\
\hline 21 & Labiatae & 5 & 3.92 & 46 & Tiliaceae & 3 & 2.94 \\
\hline 22 & Loganiaceae & 2 & 1.96 & 47 & Ulmaceae & 1 & 0.98 \\
\hline 23 & Malvaceae & 2 & 1.96 & 48 & Urticaceae & 1 & 0.98 \\
\hline 24 & Meliaceae & 1 & 0.98 & 49 & Verbanaceae & 2 & 1.96 \\
\hline 25 & Melianthaceae & 1 & 0.98 & 50 & Vitaceae & 1 & 0.98 \\
\hline & & & & & & \\
\hline
\end{tabular}

\subsubsection{Nuxia congesta-Podocarpus falcatus type}

Juniperus procera, Nuxia congesta and Maytenus undata are among the dominant tree species.

Podocarpus (Afrocarpus) falcatus is characteristic species of the type. Pittosporum viridiflorum, Maytenus undata and Myrsine africana are among the associated species of the community. Berberis holstii, Abutilon longicuspe, Heliotropium cinerascens, Buddleja polystachya and Barleria ventricosa are common in the shrub layer. Climbers such as Asparagus racemosus, 
Solanum benderianum, Clematis hirsuta and Cynanchum abyssinicum are abundant. Altitudinal distribution of the type is $2200-2390 \mathrm{~m}$ a.s.l.

\subsubsection{Acacia abyssinica - Olea europaea type}

The community type is distributed between 2000 and $2566 \mathrm{~m}$. Olea europaea is a dominant species in the tree layer and Carissa edulis in the shrub layer. Acacia abyssinica is a characteristic species of the type. Associated species include Rhus natalensis, Juniperus procera, Cadia purpurea, Dovyalis abyssinica, and Olinia rochetiana. Sarcostema vimnale and Lipia adoensis are from the shrub layer. Heracleum abyssinicum and Laggera pterodonta from the herb layer are those species recorded only in this community. Pinus patula and Cuppresus luscitanica are common exotic species of the community. Cynanchum abyssinicum, Toddalea asiatica, Solanum benderianum, Clematis simensis, Rhoicissus tridentat, Asparagus racemosus and Helinus mystacinus are climber species recorded in the community.

\subsubsection{Myrica salicifolia-Erica arborea-Maesa lanceolata type}

Myrica salicifolia is among the dominant species and Erica arborea and Measa lanceolata as characteristic species of the community. Astragalus atropilosulus, Hypericum revolutum and Clutia abyssinica are associated species of the type. Other species mainly in the shrub layer include Conyza hypoleuca and Vernonia bipontinnii. The type is found at altitude from 2650$2700 \mathrm{~m}$ a.s.l.

\subsubsection{Acacia etabaica-Dichrostachys cinerea-A. tortilis type}

This community type is found at an altitudinal distribution of 1780-1935 m a.s.l. i.e., at the lower altitude of the sampling site (Grat-Khassu). Other associated species to the dominant and character species mentioned in the type include Acacia tortilis, A. asak, A. seyal, Ziziphus spinachristi, Rhus natalensis, Carissa edulis, Canthium setiflorum, Ziziphus mucronata, Sageretia thea, Flueggea virosa and Maera angolensis. Grewia tembensis and Rhus retinorroea were the species with few frequencies in the community. 


\subsection{Plant Community-Environment Relationship}

An analysis of variance (ANOVA) of the environmental variables with plant community types is shown in Table 2. The community types don't show significant differences with respect to the environmental variables except for altitude, slope and human impact.

Table 2. Tukey's multiple range test between environmental variables and community types.

\begin{tabular}{lccccc}
\hline Variables & \multicolumn{5}{c}{ Communities } \\
\cline { 2 - 6 } Altitude (m) & $\mathbf{1}$ & $\mathbf{2}$ & $\mathbf{3}$ & $\mathbf{4}$ & $\mathbf{5}$ \\
\cline { 2 - 6 } & 2250 & 2310 & 2379 & 2674 & 1898 \\
Slope (\%) & $\mathrm{b}$ & $\mathrm{b}$ & $\mathrm{b}$ & $\mathrm{c}$ & $\mathrm{a}$ \\
& 22.14 & 23.90 & 23.08 & 31.00 & 18.00 \\
Aspect & $\mathrm{a}$ & $\mathrm{ab}$ & $\mathrm{a}$ & $\mathrm{b}$ & $\mathrm{a}$ \\
& 2.70 & 2.22 & 2.62 & 2.77 & 2.42 \\
Soil depth (cm) & $\mathrm{ns}$ & $\mathrm{ns}$ & $\mathrm{ns}$ & $\mathrm{ns}$ & $\mathrm{ns}$ \\
& 90.13 & 90.24 & 87.09 & 97.13 & 79.14 \\
Grazing & $\mathrm{ab}$ & $\mathrm{ab}$ & $\mathrm{ab}$ & $\mathrm{b}$ & $\mathrm{a}$ \\
& 0.29 & 0.55 & 1.10 & 1.00 & 1.20 \\
Human impact & $\mathrm{ns}$ & $\mathrm{ns}$ & $\mathrm{ns}$ & $\mathrm{ns}$ & $\mathrm{ns}$ \\
& 0.86 & 1.05 & 1.59 & 1.00 & 2.80 \\
No of species & $\mathrm{a}$ & $\mathrm{a}$ & $\mathrm{ab}$ & $\mathrm{a}$ & $\mathrm{b}$ \\
& 21.57 & 22.55 & 16.00 & 18.00 & 18.00 \\
& $\mathrm{~ns}$ & $\mathrm{~ns}$ & $\mathrm{~ns}$ & $\mathrm{~ns}$ & $\mathrm{~ns}$ \\
\hline
\end{tabular}

The results of Pearson's product-moment correlation of the environmental parameters show that some of the environmental parameters are correlated (Table 3). Altitude is positively correlated to soil depth and slope, and negatively correlated to human impact, species richness and aspect. Species richness decreases with increase in altitude. Slope is negatively correlated to both grazing and human impact. Grazing and human impact are positively correlated to each other and are negatively correlated to soil depth.

\subsection{Vegetation Structure}

Height and DBH measurements were used to construct the density distribution for the various categories. The distribution of trees in different height classes is shown in Fig.2 A considerable proportion of the individuals (33.3\%) belong to the lowest height classes i.e. $(<2 \mathrm{~m})$. Only few individuals (4.2\%) attain heights of more than $21 \mathrm{~m}$. 
Table 3. Pearson's product-moment correlation coefficient for correlations between environmental variables.

\begin{tabular}{|l|r|r|r|r|r|r|r|}
\hline & altitude & slope & aspect & $\begin{array}{c}\text { soil } \\
\text { depth }\end{array}$ & grazing & $\begin{array}{c}\text { human } \\
\text { impact }\end{array}$ & $\begin{array}{c}\text { Number of } \\
\text { species }\end{array}$ \\
\hline altitude & 1.000 & & & & & & \\
\hline slope & .035 & 1.000 & & & & & \\
& .766 & & & & & & \\
\hline aspect & -.025 & .176 & 1.000 & & & & \\
& .832 & .133 & & & & & \\
\hline soil depth & .244 & .042 & .010 & 1.000 & & & \\
& .023 & .722 & .931 & & & & \\
\hline grazing & .029 & -.007 & .086 & -.161 & 1.000 & & \\
& .808 & .952 & .465 & .172 & & & \\
\hline human impact & $-.296^{\star}$ & .005 & .208 & -.354 & $.704^{\star *}$ & 1.000 & \\
& .010 & .964 & .075 & .002 & .000 & & \\
\hline Number of & $-.342^{\star \star}$ & .137 & .011 & -.128 & -.136 & -.018 & \\
species & .000 & .142 & .925 & .278 & .249 & .879 & \\
\hline
\end{tabular}

**. Correlation is significant at the 0.01 level

*. Correlation is significant at the 0.05 level

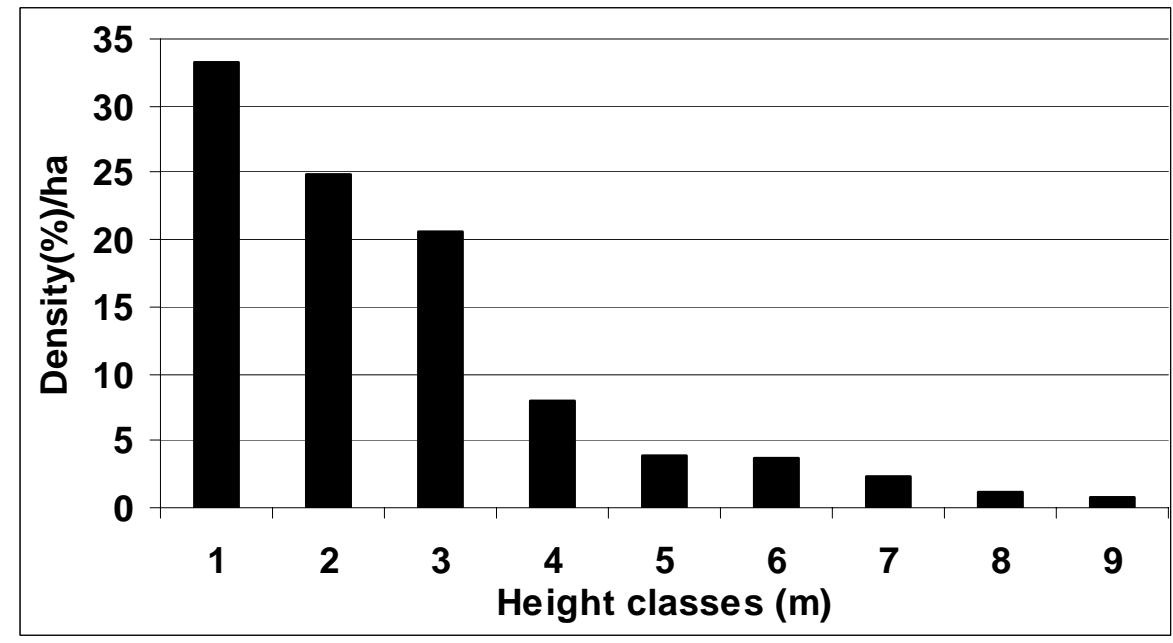

Figure 2. Density (\%)/ha of tree/shrub in different height classes. Class1=<2m; 2=2-5; 3=6-9; $4=10-13 ; 5=14-17 ; 6=18-21 ; 7=22-25 ; 8=26-29 ; 9=>29$.

DBH measurements reveal a trend similar to that of the height distribution (Fig.3). Most individuals have a diameter less than $20 \mathrm{~cm}$ (86\%). About 36.4\% belong to the lowest diameter class $(<2 \mathrm{~cm})$, and $19.1 \%$ to the next higher class $(2-5 \mathrm{~cm})$. Only $0.4 \%$ have DBH grater than 50 $\mathrm{cm}$. The result confirms that the number of individuals decreases as the height and $\mathrm{DBH}$ of the individual's increase. 


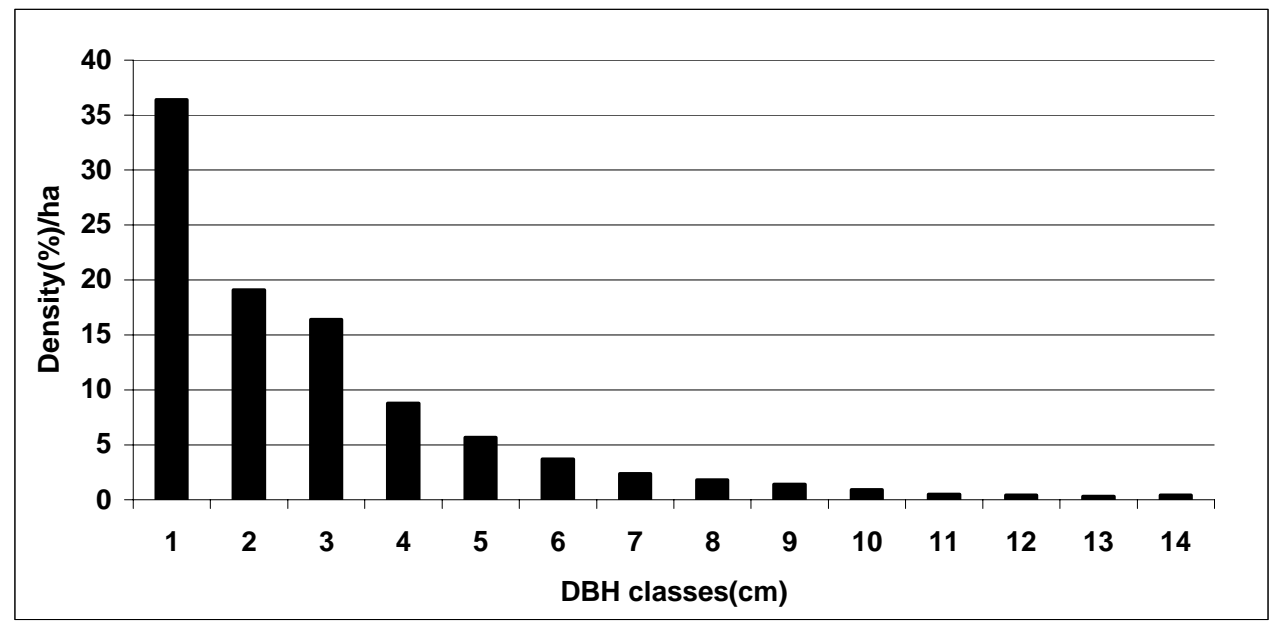

Figure 3. Density (\%) of tree/shrub/ha at different DBH classes. Class1 $=<2 \mathrm{~cm} ; 2=2-5$; 3=6-9; $4=10-13 ; 5=14-17 ; 6=18-21 ; 7=22-25 ; 8=26-29 ; 9=30-33 ; 10=34-37 ; 11=38-41 ; 12=42-$ $45 ; 13=46-49 ; 14=>50$.

Table 4. Importance Value Index of the most dominant tree/shrub species of the study area.

\begin{tabular}{|c|c|c|c|c|c|}
\hline Scientific name & $\begin{array}{l}\text { Relative } \\
\text { Density }\end{array}$ & $\begin{array}{l}\text { Relative } \\
\text { Frequency }\end{array}$ & $\begin{array}{l}\text { Relative } \\
\text { Dominance }\end{array}$ & $\begin{array}{l}\text { Importance } \\
\text { Value Index (IVI) }\end{array}$ & $\begin{array}{l}\text { IVI } \\
\text { Rank }\end{array}$ \\
\hline Juniperus procera & 14.47 & 8.35 & 30.34 & 53.16 & 1 \\
\hline Olea europaea subsp. cuspidata & 9.44 & 6.96 & 19.97 & 36.37 & 2 \\
\hline Nuxia cogesta & 8.94 & 6.50 & 11.22 & 26.66 & 3 \\
\hline Cassipourea malosana & 8.75 & 5.57 & 6.17 & 20.49 & 4 \\
\hline Olinia rochetaina & 9.63 & 6.19 & 3.75 & 19.55 & 5 \\
\hline Rhus natalensis & 6.23 & 7.58 & 1.26 & 15.07 & 6 \\
\hline Rhus glotinosa & 4.59 & 6.50 & 2.04 & 13.13 & 7 \\
\hline Acacia abyssinica & 3.02 & 5.26 & 2.09 & 10.37 & 8 \\
\hline Podocarpus falcatus & 5.48 & 2.47 & 1.40 & 9.35 & 9 \\
\hline Ekebergia capensis & 2.10 & 3.86 & 3.17 & 9.13 & 10 \\
\hline Allophylus macrobotrys & 1.45 & 2.32 & 5.34 & 9.11 & 11 \\
\hline Pittosporum viridiflorum & 2.39 & 5.10 & 1.26 & 8.75 & 12 \\
\hline Bersama abyssinica & 2.51 & 4.95 & 0.62 & 8.08 & 13 \\
\hline Celtis africana & 2.52 & 4.02 & 1.50 & 8.04 & 14 \\
\hline Calpurnia aurea & 2.52 & 4.33 & 0.27 & 7.12 & 15 \\
\hline Osyris quadripartita & 2.01 & 4.79 & 0.30 & 7.1 & 16 \\
\hline Ficus sur & 1.20 & 1.85 & 3.81 & 6.86 & 17 \\
\hline Teclea simplicifolia & 1.95 & 3.56 & 0.88 & 6.39 & 18 \\
\hline Dovyalis abyssinica & 2.14 & 2.94 & 0.56 & 5.64 & 19 \\
\hline Dombeya torrida & 0.94 & 4.31 & 0.05 & 5.3 & 20 \\
\hline Acacia etbaica & 3.27 & 0.77 & 1.23 & 5.27 & 21 \\
\hline Myrica salicifolia & 1.51 & 0.77 & 1.99 & 4.27 & 22 \\
\hline Acacia tortilis & 1.95 & 0.77 & 0.75 & 3.47 & 23 \\
\hline Maytenus arbutifolia & 1.01 & 1.39 & 0.08 & 2.48 & 24 \\
\hline Total & 100 & 100 & 100 & 300 & \\
\hline
\end{tabular}


Density distribution over DBH and height classes of the most dominant species follows the same trend as that of the relative basal area. Juniperus procera attain highest sizes and is the most dominant tree in the area.

The dominant tree species that represent the forest structure Juniperus procera and Olea europaea subsp. cuspidata have individuals distributed in all the height and DBH classes. While Olinia rochetiana and Cassipourea malosana have high number of individuals below $13 \mathrm{~m}$ in height and $21 \mathrm{~cm}$ in DBH and no individuals above $21 \mathrm{~m}$ in height and $45 \mathrm{~cm}$ in DBH.

Relative density, relative frequency, relative dominance and importance value index were computed for 24 tree/shrub species with $\mathrm{DBH}$ greater than $10 \mathrm{~cm}$ and relative frequency greater than $0.60 \%$. The results of the analysis are presented in Table 4.

\section{DISCUSSION}

Five community types were identified from the classification strategies. These include community types $1,2,3,4$, and 5 .

Community type 1, which is dominated by Allophylus macrobotrys and characterized by Ficus sur, is found in specialized habitats such as along river courses. The stands sampled in this type are located at the middle of the forest, which is less grazed by cattle and its human impact is found to be low. Regenerating species of Hagenia abyssinica and Podocarpus (Afrocarpus) falcatus are common here.

Community type 2 with good timber species: Juniperus procera, Olea europaea subsp. cuspidata and Podocarpus falcatus has experienced human interference in the form of selective cutting. Cattle interferences were also observed in some of its stands.

Community type 3 is rich in shrub layer species and woody climbers. The stands sampled in this community are located in an area having shallow soils with medium human interference in the form of firewood collection and selective cutting. This might be due to being near to the farmers settlement area. Although most area of this stands was highly affected before about 20 years being used as farming land, by now it is in good regeneration status. In most of its stands introduced exotic species of Cuppresus lusitanica and Pinus patula have been observed.

Community type 4 Myrica salicifolia-Erica arborea-Maesa lanceolata distributed at higher altitudes of the sampling site is unique in its own type having species different from other types. This community is surrounded by upper slope and bare rock area, thus little disturbance by 
human and cattle is encountered. Even though lianas are not recorded in this type it is having good species richness.

Community type 5 is highly influenced by people collecting firewood, charcoal making and grazing animals. This is due to its being nearby to Alamata town and having species of plants suitable for charcoal making and firewood. The stands of this community are from an area, which is at lower altitudes, having shallow soil and that receives lower amount of annual rainfall with higher temperature.

The community types don't show significant difference $(\mathrm{P}<0.05)$ with respect to the environmental variables except for altitude and slope. The major discriminate among the community types is due to altitude. This is in line with the result observed by Kumlachew Yeshitla and Tamrat Bekele (2002) and Zerihun Woldu et al. (1989). The community types could be grouped into three based on altitude: group 1 with altitude 2250-2379 m (types 1, 2 and 3), group 2 community number 4 and group 3 community number 5 (with P value of 0.124 ). On the other hand, the communities were grouped in one in respect to aspect, grazing and number of species. All communities were homogenous with a $\mathrm{P}$ value of 0.651 in respect to aspect.

Density distribution at different height classes in the study area showed that $33.3 \%$ of the individuals have a height less than 2 meters and $24.9 \%$ fall between 2-5 meters range. Figure 2 shows that $78.8 \%$ of all individuals are 9 meter or shorter. Individuals greater than 29 meters in height are rare $(0.7 \%)$. Thus the study confirms that the number of individuals decreased as the height of the individuals increased indicating long time disturbance (thus less mother trees). Such result was also observed in Chilmo forest by Tamrat Bekele (1993).

Density distribution at different DBH classes also showed similar trend as that of height class distribution. It indicates dominance of small sized individuals. The pattern of such density can be an indicator for community dynamics in the forest. The total number of trees/shrubs in each DBH classes decreased with an increasing in DBH classes. This relationship also was observed in Dessa forest by Gebremedhin Hadera (2000); in Chilmo and Menagesha forests (Tamrat Bekele, 1993) and the tropical lowland rain forest of Los Tuxtlas, Mexico (Bongers et al., 1988). The forest pattern is formed by the species structure with reversed $J$ shaped in DBH class distribution. $36.4 \%$ of the individuals in the forest have DBH less than $2 \mathrm{~cm}$ (Fig. 3).

Relative density distribution of the species showed Juniperus procera (14.47\%) followed by Olinia rochetania (9.63\%) and Olea europaea subsp. cuspidata (9.44\%) to have the highest 
relative density compared to the others. About twenty-nine per cent of the tree/shrub species have a relative density greater than five, while $70 \%$ of the species have a relative density of less than 5 \%. Analysis of the frequency distribution indicated that Juniperus procera, Rhus natalensis, Olea europaea subsp. cuspidata, Nuxia congesta, Rhus glutinosa and Olinia rochetania were found to be with the highest relative frequency indicating their good distribution throughout the forest (Table 4). Relative dominance, which is the basal area of a single species, divided by total basal area of the species ranges from $0.05 \%$ (Dombeya torrida) to $30.34 \%$ (Juniperus procera). Thus the contribution of each species to the basal area differs from one another. Species such as Juniperus procera, Olea europea subsp.cuspidata, and Nuxia congesta have the highest basal area percentage ranging from $11.22 \%$ to $30.34 \%$ being Juniperus procera and Olea europea sharing high basal area $30.34 \%$ and $19.97 \%$ and importance value index $53.16 \%$ and $36.37 \%$ respectively.

\section{CONCLUSION}

The survey showed that the forest is dominated by small sized tree and shrub species in secondary stage of development, indicating that the forest was heavily exploited and affected in the previous periods, but good regeneration is in process at the present time. Therefore, to improve the natural diversity and structure of the forest, to minimize the influence of the surrounding communities and utilize the forest resources sustainably for present and future generation, the basic needs and traditional rights of the communities over the uses of forest resources should be recognized. The much-needed positive attitudes towards forest protection and development can only be obtained from the rural communities through the development of a genuine benefit sharing mechanism. Thus community participation is quite important.

\section{ACKNOWLEDGMENT}

We would like to thank Dr. Tesfaye Bekele, head of Forest Resources Conservation (MoA), who have provided us with a vehicle during reconnaissance survey. We are grateful to Ato Gebremedhin Hadera, head, and manager of woody biomass inventory and strategic planning project, and Ato G/Kidan Teklu, Natural Resources Conservation Department (MoA), for their material (Hypsometer, DBH caliper) and moral support. Thanks to National Metrological Service Agency for providing metrological data of the study area. We thank Swedish Agency for 
Research with Developing Countries (SAREC/SIDA) and Research Programme on the Sustainable Utilization of Dryland Biodiversity (RPSUD) for covering the costs of the research.

\section{REFERENCES}

Andreucci, F., Biondi, E., Feoli, E \& Zuccarello, V. 2000. Modeling environmental responses of plant associations by fuzzy set theory. Community Ecology 1(1): 73-80.

Bongers, F., Popma, J., Castillo, M.D \& Carabias, J. 1988. Structucture and floristic composition of the lowland rain forest of Los Tuxtlas, Mexico. In: Bongers, F. and Popma, J (eds.), Trees and gaps in a Mexican tropical rain forest, Plant ecology, Mexico, pp.13-40.

Braun-Blanquet, J. 1965. Plant sociology: the study of plant communities. Koeltz Scientific Books, Germany. 439pp.

Bridson, D \& Forman, L (eds.). 1992. The herbarium handbook. Royal Botanical Gardens Kew. Whitstable Litho Printers Ltd. Great Britan. 303pp.

Edwars, S., Mesfin Tadesse \& Hedberg, I. 1995. Flora of Ethiopia and Eritrea. Vol 2, Part 2, Canellaceae to Euphorbiaceae. Addis Ababa, Ethiopia, Uppsala, Sweden, 456pp.

Edwars, S., Mesfin Tadesse, Sebsebe Demissew \& Hedberg, I. 2000. Flora of Ethiopia and Eritrea, Volume 2, Part 1, Magnoliaceae to Flacourtiaceae. Addis Ababa, Ethiopia,Uppsala, Sweden, 532pp.

Edwars, S., Sebsebe Demissew \& Hedberg, I. 1997. Flora of Ethiopia and Eritrea. Volume 6, Hydrochritaceae to Arecaceae. Addis Ababa, Ethiopia, Uppsala, Sweden, 586pp.

Feoli, E (ed.). 1996. Rehabilitation of degraded and degrading areas of Tigray, Northern Ethiopia. Final project report, commission of the European Communities (CEC). 411pp.

Gauch, H.G \& Whittaker, R.H. 1981. Heirarchical classification of community data. Journal of ecology, 69: 135-52.

Gebremedhin Hadera. 2000. A study on the ecology and management of the Dessa forest in the northeastern escarpment of Ethiopia. M.Sc. Thesis A.A.U.

Hedberg, I \& Edwards, S (eds.). 1989. Flora of Ethiopia. Volume 3, Pittosporaceae to Araliaceae. Addis Ababa, and Asmara, Ethiopia, Uppsala, Sweden, 660pp.

Hedberg, I., Edwards, S \& Sileshi Nemomessa. 2003. Flora of Ethiopia and Eritrea. Volume 4, Part 1, Apiaceae to Dipsacaceae. Addis Ababa, Ethiopia. 
Hill, M.O. 1979. TWINSPAN: A FORTRAN program for arranging multivariate data in an ordered two-way table by classification of individuals and attributes. Ecology and sytematics, Cornell University, Ithaca, New York.

Kebrom Tekle, Backeus, I., Skuglund, J \& Zerihun Woldu. 1997. Vegetation on hillslopes of Wello, Ethiopia: Degradation and regeneration. Nord. J. Bot., 17(5): 483-493.

Kumelachew Yeshitla \& Tamrat Bekele. 2002. Plant community analysis and ecology of afromontane and transitional rainforest vegetation of Southwestern Ethiopia. SINET:Ethiop.J.Sci., 25(2):155-175.

Legesse Negash. 2002. Review of research advances in some selected African trees with special reference to Ethiopia. Ethiop.J.Biol.Sci., 1(1): 81-126.

Martin, G.J. 1995. Ethnobotany: a methods manual. Chapman and Hall, London. 268pp.

Misra, K.C. 1974. Manual of plant ecology. Oxford and IBH publishing Co., New Delhi. 376p.

Mitku Haile \& Kindeya Gebremedhin. 2000. Efforts to rehabilitate degraded lands: local initiative for planning resource management in Tigray. In: Feoli, E., Pottier, D. and Zerihun Woldu (eds.), Proceeding of the international workshop on sustainable development of Dryland areas of East Africa, November $9^{\text {th }}-12^{\text {th }} 1988$, University of Trieste, Italy, 319-330.

Muller-Dombois \& Ellenberg, H. 1974. Aims and methods of vegetation ecology. John Willey and Sons, Inc, U.S.A. 547pp.

Parent, G. 2000. Manual for woody biomass inventory. Woody Biomass Inventory and Strategic Planning Project, Ministry of Agriculture, Addis Ababa, Ethiopia, 113pp.

SFCDD (State Forests Conservation and Development Department) 1990. Ethiopian Forest Resource Base Identification, Conservation and Rational use in Ethiopia. SFCDD, Addis Ababa.

SFCDD. 1997. Management plan for Huguburda-Gratkhassu forest. Addis Ababa.

Tamrat Bekele. 1993. Vegetation ecology of remnant Afromontane forests on the central plateau of Shewa, Ethiopi. Acta Phytogeographica, Sukecica, 79:1-59.

Tesfaye Awas, Tamrat Bekele \& Sebsebe Demisew, 2001. An ecological study of the vegetation of Gambella region, Southern western Ethiopia. SINET: Ethiop. J. Sci., 24(2):213-228. 
Tewolde Brhane GebreEgziabher. 1990. Diversity of Ethiopian flora. In: Engles, J.M.M., Hawkes, J.G and Melaku Worede (eds.), Plant genetic resources of Ethiopia, Cambridge University Press, Cambridge, pp.75-81.

Tuxill, J \& Nabhan, G.P. 2001. People, plants and protected areas. Earthscan publication Ltd, London and Sterling, 248pp.

van der Maarel, E. 1979. Transformation of cover/abundance values in phytosociology and its effect on community similarity. Vegetatio, 39: 97-114.

van der Maarel, E., Janssen, J.G.M \& Louppen, J.M.W. 1978. TABORED, a program for structuring phytosociological tables. Vegetatio, 38: 143-156.

von Breintenbach, G. 1963. Indigenous Trees of Ethiopia. Ethiopian Forestry Association, Addis Ababa.

WCMC (World Conservation Monitoring Center) 1992. Global Biodiversity: status of the earth’s living resourceces. Champman and Hall, London, 585pp.

Werger, M. 1974. Concepts and techniques applied in the Zurich-Montpellier method of vegetation survey. Bothalia, 11(3): 309-323.

Zenebe GebreEgziabher, Werede Sisay \& Tirungo W/Michael. 1998. Socio-economic suvey of Hugumburda-Gratkhassu State Forest, Tigray National Regional State, Bureua of Agriculture and Natural Resources, Ethiopia.

Zerihun Woldu \& Backeus, I. 1991.The shrub land vegetation in Western Shewa, Ethiopia and its possible recovery. Journal of vegetation science, 2: 173-180.

Zerihun Woldu, Dragan, M., Feoli, E \& Fernetti, M. 2002. Reducing soil erosion in Northern Ethiopia, Adwa Zone, through a special decision support system (SDSS). Ethiopian J. Biol. Sci., 1(1): 1-12.

Zerihun Woldu, Feoli, E \& Lisanework Nigatu. 1989. Partitioning an elevation gradient of vegetation from southeastern Ethiopia by probabilistic methods. Vegetatio, 81:189-198.

Zewge Teklehaimanot \& Healey, J. 2001. Biodiversity conservation in ancient church and Monastry Yards in Ethiopia. In: Proceedings of a workshop on biodiversity conservation held in Addis Ababa 1-2 August 2001, Ethiopian Wildlife and Natural History Society, Addis Ababa, Ethiopia, pp.2-4. 


\section{Appendix 1}

List of plant Taxa collected in the study area with corresponding coll. no., family, vernacular name and habit

\begin{tabular}{|c|c|c|c|c|}
\hline \begin{tabular}{|l} 
Col. \\
No \\
\end{tabular} & SPECIES NAME & Family & \begin{tabular}{|l|} 
Vernacular \\
Name (Tigregna)
\end{tabular} & Habit \\
\hline 078 & Barleria ventricosa Hochest.exNees & Acanthaceae & & Shrub \\
\hline 007 & Rhus glutinosa A.Rich. & Anacardiaceae & Tetaelo & Tree/Shrub \\
\hline 024 & R. natalensis Krauss9 & Anacardiaceae & Atam & Tree \\
\hline 053 & R. retinorrhoea Oliv. & Anacardiaceae & Nefasito & Shrub \\
\hline 100 & Heracleum abyssinicum (Boiss.) Norman & Apiaceae & & Herb \\
\hline 034 & Heteromorpha trifoliata (Wendel.) Eckl. and Zeyh. & Apiaceae & Mometse Akeytay & Shrub \\
\hline 039 & Acokanthera schimperi (A.DC.) Benth. & Apocynaceae & Meroz & Tree/Shrub \\
\hline 028 & Carissa edulis (Forssk.) Vahl & Apocynaceae & Egam & Shrub \\
\hline 077 & Cynanchum abyssinicum Decn. & Asclepiadaceae & Hareg-gumgumo & Climber \\
\hline 093 & Gomphocarpus fruticosus (L.) Ait.f. & Asclepiadaceae & Enchie & Shrub \\
\hline 094 & Sarcostemma viminale (L.) R.Br. & Asclepiadaceae & Tsibtsibo & Shrub \\
\hline 047 & Asparagus racemosus Willd. & Asparagaceae & Kestensto & ClimbIng shrub \\
\hline 019 & Conyza hypoleuca A.Rich. & Asteraceae & Tsaeda-kotsilo & Shrub \\
\hline 099 & Laggera pterodonta (DC.) Schulz. Bip.ex A.Rich. & Asteraceae & & Herb \\
\hline 091 & Laggera tomentosa (Sch.Bip.ex.A.Rich.) Oliv. \& Hiern & Asteraceae & Kanskanso & Shrub \\
\hline 072 & Senecio hadiengis Forssk. & Asteraceae & Suhumatali & Shrub \\
\hline 011 & Vernonia amygdalina Del. & Asteraceae & Girawa & Tree \\
\hline 082 & V. rueppelli Sch Bip. & Asteraceae & Tetaso & Tree \\
\hline 003 & V. bipontinnii Vatke. & Asteraceae & Mechalo & Shrub \\
\hline 056 & Balanites aegyptiaca (L.) Del. & Balanitaceae & Bedano & Tree \\
\hline 090 & Berberis holstii Engl. & Berberidaceae & Mucha-eff & Shrub \\
\hline 076 & Cordia africana Lam. & Boraginaceae & Awhi & Tree \\
\hline 037 & Ehretia cymosa Thonn. & Boraginaceae & Tuwlaga & Tree/Shrub \\
\hline 079 & Heliotropium cinerascens Steud.exDC. & Boraginaceae & Am-am-gimel & Shrub \\
\hline 096 & Opuntia ficus-indica (L.) Mill & Cactaceae & Beles-kolkola & Shrub \\
\hline 061 & Maerua angolensis DC. & Capparidiaceae & Kormediet & Shrub \\
\hline 075 & Maytenus arbutifolia (A.Rich.) Wilczek & Celastraceae & Dawija & Tree/Shrub \\
\hline 009 & M. undata (Thunb.) Blakelock & Celastraceae & Ats-ats & Tree/Shrub \\
\hline 022 & Cupressus lusitanica Miller & Cupressaceae & Tsihdi-ferenji & Tree \\
\hline 002 & Juniperus procera Hochst.ex.Endl. & Cupressaceae & Tsihdi-adi & Tree \\
\hline 029 & Euclea racemosa subsp. schimperi (A.DC.) Dandly & Ebenaceae & Kuliow & Shrub \\
\hline 018 & Erica arborea $L$. & Ericaceae & Hasta & Shrub \\
\hline 015 & Clutia abyssinica Jaub. \& Spach. & Euphorbiaceae & Hirtmtmo & Shrub \\
\hline 063 & Flueggea virosa (Wild.) Voigt & Euphorbiaceae & & Shrub \\
\hline 023 & Acacia abyssinica Hochst.ex Benth. & Fabaceae & Chia & Tree \\
\hline 055 & A. asak (Forssk.) Will. & Fabaceae & Sabansa & Tree/Shrub \\
\hline 050 & A. etbaica Schweinf. & Fabaceae & Sraw & Tree \\
\hline 059 & A. seyal Del. & Fabaceae & Wancho & Tree \\
\hline 051 & A. tortilis (Forssk.) Hayne & Fabaceae & Karora & Tree \\
\hline 005 & Astragalus atropilosulus (Hochst.) Bunge & Fabaceae & Tetem-agazen & Shrub \\
\hline 074 & Cadia purpurea (Picc.) Ait. & Fabaceae & Shilaen & Shrub \\
\hline
\end{tabular}




\begin{tabular}{|c|c|c|c|c|}
\hline 042 & Calpurnia aurea (Ait) Benth. & Fabaceae & Hitsawits & Tree/Shrub \\
\hline 066 & Senna sinqueana (Del.)Lock & Fabaceae & Hambahambo & Shrub \\
\hline 098 & Colutea abyssinica Kunth and Bouche & Fabaceae & Que-queta & Shrub \\
\hline 058 & Dichrostachys cinerea (L.) Wight and Arn. & Fabaceae & Harshmersha & Shrub \\
\hline 033 & Pterollobium stellatum (Forssk.) Brenan & Fabaceae & Konteftefe & Shrub \\
\hline 012 & Dovyalis abyssinica (A.Rich.) Warb. & Flacourtiaceae & Mengolhats & Tree/Shrub \\
\hline 032 & D. verrucosa (Hochst.) Warb. & Flacourtiaceae & Tuemtenay & Shrub \\
\hline 004 & Hypericum revolutum Vahl. & Hypericaceae & Abedi & Tree/Shrub \\
\hline 073 & Becium grandiflorum (Lam.) Pichi-serm. & Lamiaceae & Tebeb & Shrub \\
\hline 025 & Clerodendron myricoides (Hochst.) Vatke & Lamiaceae & Shewha & Shrub \\
\hline 102 & Meriandra bengalensis (Konig ex. Roxb.) Benth. & Lamiaceae & Mesaguh & Shrub \\
\hline 036 & Otostegia fruticosa (Forssk.) Schweif.ex Penzing & Lamiaceae & Chamo & Shrub \\
\hline 095 & O. integrifolia Benth & Lamiaceae & Chi-endog & Shrub \\
\hline 092 & Buddleja polystachya Fresen & Loganiaceae & Metere & Shrub \\
\hline 016 & Nuxia congesta R.Br.ex.Fresen & Loganiaceae & Tekarie & Tree \\
\hline 086 & Abutilon hirtum (Lam.) Sweet & Malvaceae & Necha & Shruby herb \\
\hline 081 & A. longicuspe Hochest.exA.Rich. & Malvaceae & Thaeda-necha & Shruby herb \\
\hline 043 & Ekebergia capensis Sparrm. & Meliaceae & Kot & Tree \\
\hline 010 & Bersama abyssinica Fresen. & Melianthaceae & Mirkuz-zibe & Tree/Shrub \\
\hline 083 & Ficus palmata Forssk. & Moraceae & Beles & Tree/Shrub \\
\hline 069 & F. sur Forssk. & Moraceae & Shanfa & Tree \\
\hline 001 & Myrica salicifolia A.Rich. & Myricaceae & Shihnet & Tree/Shrub \\
\hline 014 & Myrsine africana L. & Myricinaceae & Kechemo & Shrub \\
\hline 008 & Maesa lanceolata Forssk. & Myrsinaceae & Saweria & Tree \\
\hline 080 & Jasminum grandiflorum (R.Br.ex.Fresen.) P.S.Green & Oleaceae & Tselim-habi & Climber \\
\hline 027 & Olea europaea subsp cuspidate (Wall. ex DC.) Cifferri & Oleaceae & Awlie & Tree \\
\hline 006 & Olinia rochetania A.Juss. & Oliniaceae & Ale-ale & Tree \\
\hline 085 & Phytolacca dodecandra LHerit. & Phytolaccaceae & Shimti & Shrub \\
\hline 089 & Pinus patula L. & Pinaceae & Bush & Tree \\
\hline 026 & Pittosporum viridiflorum Sims & Pittosporaceae & Mayliho & Tree/Shrub \\
\hline 087 & Podocarpus (Afrocarpus) falcatus (Thun) Mirb. & Podocarpaceae & Zigba & Tree \\
\hline 030 & Rumex nervosus Vahl & Polygonaceae & Enbacho & Shrub \\
\hline 067 & Clematis hirsuta Perr and Guill & Ranunculaceae & Hareg-hazo & ClimbIng shrub \\
\hline 048 & Clematis simensis Fresen. & Ranunculaceae & Hareg-thirae & Woody climber \\
\hline 064 & Helinus mystacinus (Ait.) E.Mey.ex Steud. & Rhamnaceaae & & Woody climber \\
\hline 045 & Sageretia thea (Osbeck) M.C.Johnston & Rhamnaceae & Kenchelchele & Shrub \\
\hline 057 & Ziziphus mucronata Willd. & Rhamnaceae & Kunkura-hido & Shrub \\
\hline 052 & Z. spina-christi (L.) Desf. & Rhamnaceae & KunkuraGeba) & Shrub \\
\hline 054 & Cassipourea malosana (Baker) Alston & Rhizophoracea & Keyh-om & Tree \\
\hline 101 & Hagenia abyssinica (Bruce) J.F.Gmel. & Rosaceae & Habi & Tree \\
\hline 017 & Rosa abyssinica Lindely & Rosaceae & Kaga & Shrub \\
\hline 065 & Rubus steudneri Schweinf. & Rosaceae & Mengolel & Shrub \\
\hline 060 & Canthum setiflorum Hiern. & Rubiaceae & & Shrub \\
\hline 070 & Pavetta oliveriana Hiern & Rubiaceae & Shumeja & Shrub \\
\hline 035 & Psydrax schimperiana (A.Rich.) Bridson & Rubiaceae & Tsehag & Shrub \\
\hline 038 & Teclea simplicifolia (Engl.) Verdoorn & Rutaceae & Salih & Tree/Shrub \\
\hline
\end{tabular}




\begin{tabular}{|l|l|l|l|l|}
\hline 049 & Toddalia asiatica (L.) Lam. & Rutaceae & Hareg & Woody climber \\
\hline 013 & Osyris quadripartite Decn. & Santalaceae & Kerets & Tree \\
\hline 068 & Allophylus macrobotrys Gilg & Sapindaceae & Meara & Tree/Shrub \\
\hline 020 & Dodonaoea angustifolia L.f. & Sapindaceae & Tahsos & Shrub \\
\hline 021 & Discopodium penninervium Hochst. & Solanaceae & Alhim & Tree \\
\hline 088 & Solanum benderianum Schimper ex Engl. & Solanaceae & & Climber \\
\hline 071 & S. schimperianum Hochst. ex A.Rich. & Solanaceae & Berbereawald & Shrub \\
\hline 031 & Dombeya torrida (J.F.Gmel.) P. Bamps & Sterculiaceae & Buyak & Tree/Shrub \\
\hline 046 & Grewia ferruginea Hochst.exA.Rich. & Tiliaceae & Meleglega & Tree/Shrub \\
\hline 041 & G. mollis Juss. & Tiliaceae & Reway & Tree/Shrub \\
\hline 062 & G. tembensis Fresen. & Tiliaceae & Chaka & Shrub \\
\hline 040 & Celtis africana Burm.f. & Ulmaceae & Moto-koma & Tree \\
\hline 084 & Debregeasia bicolar (Roxb.) Wedd. & Urticaceae & May-awalie & Shrub \\
\hline 097 & Lippia adoensis Hochst.ex Walp. & Verbanaceae & Kusihe & Shrub \\
\hline 044 & Rhoicissus tridentata (L.f.) Wild and Drummond & Vitaceae & Keyh-hareg & Woody climber \\
\hline
\end{tabular}

